\title{
UPAYA MENEKAN ANGKA KEMISKINAN SERTA PEMERATAAN PENDAPATAN NASIONAL MELALUI PEMBANGUNAN EKONOMI BERBASIS ZAKAT
}

\author{
Dwi Ratna Indri Hapsari \\ Fakultas Hukum Universitas Muhammadiyah Malang \\ J1. Raya Tlogomas No. 246 Malang \\ Email: indri3009@gmail.com
}

\begin{abstract}
Poverty is a state of people who are not able to meet their needs. As a result, people cannot live a decent so that their standard of living decline. Differences of community groups with specific earnings income gaps cause problems. Therefore, the necessary role of government in equalizes the distribution of income distribution. Starting from the economic problems then came the idea of sharia, namely optimization zakat is obligatory for Muslims to remember Indonesia is the country with the largest Muslim population in the world. Indonesia is not a religious country, but a country with a predominantly Muslim, the middle ground is needed, namely the role of the state and society in the two positions together. When zakat management is conducted in accordance with Islamic law, the mandate, expediency principle, justice and the rule of law as well as integrated it can undoubtedly reduce poverty and income inequality in Indonesian.
\end{abstract}

Keywords: poverty, economic development, zakat, welfare

\begin{abstract}
Abstrak
Kemiskinan merupakan keadaan masyarakat yang tidak mampu memenuhi kebutuhan hidupnya. Akibatnya, masyarakat tidak dapat hidup secara layak sehingga taraf hidupnya menurun. Perbedaan kelompok masyarakat dengan penghasilan tertentu menimbulkan permasalahan kesenjangan penghasilan. Oleh karena itu, diperlukan peran pemerintah dalam memeratakan penyaluran distribusi pendapatan. Berawal dari permasalahan ekonomi tersebut kemudian muncul gagasan syariah yaitu pengoptimalan zakat yang merupakan kewajiban bagi umat Islam mengingat Indonesia merupakan negara dengan penduduk beragama Islam terbanyak di Dunia. Indonesia bukan negara agama, tetapi negara dengan mayoritas berpenduduk Muslim, diperlukan jalan tengah, yakni peran negara dan masyarakat dalam dua posisi yang bersinergi. Ketika pengelolaan zakat dilaksanakan sesuai dengan syariat Islam, amanah, berasaskan kemanfaatan, keadilan dan kepastian hukum serta terintegrasi maka niscaya dapat menekan angka kemiskinan dan ketimpangan pendapatan masyarakat di Indonesia.
\end{abstract}

Kata kunci: kemiskinan, pembangunan ekonomi, zakat, kesejahteraan 


\section{A. Pendahuluan}

Kegiatan ekonomi memiliki peran yang sangat penting dalam berbagai aspek kehidupan. Masyarakat dalam pemenuhan kebutuhannya melakukan kegiatan ekonomi. Kegiatan ekonomi merupakan segala kegiatan yang dilakukan untuk memenuhi kebutuhan hidup. Permasalahan ekonomi yang terjadi di suatu negara dapat memperlambat laju pertumbuhan ekonomi. Di Indonesia permasalahan ekonomi dapat menghambat terwujudnya dan kesejahteraan masyarakat. Permasalahan ekonomi yang dialami Indonesia yang mendasar adalah Kemiskinan. Kemiskinan merupakan keadaan masyarakat yang tidak mampu memenuhi kebutuhan hidupnya. Kebutuhan hidup meliputi makanan, pakaian, tempat tinggal, pendidikan, dan kesehatan. Kemiskinan sebagai akibat berkurangnya pendapatan masyarakat secara riil. Masyarakat mengalami penurunan daya beli barang-barang kebutuhan pokok secara umum. Akibatnya, masyarakat tidak dapat hidup secara layak sehingga taraf hidupnya menurun.

Penyebab kemisikinan sangat banyak, antara penyebab dan akibat sering berbalik misalnya miskin disebabkan pendidikan rendah, juga pendidikan rendah disebabkan miskin. Penyebab dan jenis-jenis kemiskinan belum ada yang baku atau standar, sering terjadi tumpang tindih. Secara garis besarnya dapat diungkapkan antara lain ${ }^{1}$ :

1. Kemiskinan alami (natural) adalah kemiskinan yang disebabkan keadaan alam suatu daerah yang miskin. Contohnya dulu di daerah Gunung Kidul yang tanahnya/alamnya sangat miskin sehingga penduduknya banyak yang miskin. Kemiskinan ini hanya dapat di atasi dengan bantuan dari luar daerah.

2. Kemiskinan budaya (kultural) adalah kemiskinan yang disebabkan kondisi sosial budaya penduduk di daerah itu mendukung kemiskinan. Contoh di Nias karena banyaknya pesta adat sehingga terjadi utang adat dan akhirnya mereka menjadi miskin. Kemiskinan ini sangat sulit dan membutuhkan waktu yang lama untuk diatasi.

3. Kemiskinan struktur (structural) adalah kemiskinan yang disebabkan keadaan struktur pemerintahan, struktur pendistribusian fasilitas yang membuat suatu daerah penduduknya menjadi miskin. Contoh, penduduk di luar Jawa banyak miskin karena hasil minyak lebih banyak digunakan di Jawa.

Berdasarkan data Badan Pusat Statistik (BPS) bulan Maret 2013 jumlah penduduk yang berada dalam garis kemiskinan berjumlah sekitar 28,07 juta jiwa (11,37\%). ${ }^{2}$ Meskipun jumlah kemiskinan di Indonesia semakin menurun setiap tahunnya, namun hal tersebut masih sangat jauh untuk menjangkau Indonesia sebagai negara kesejahteraan. Selain kemiskinan Kesenjangan Penghasilan juga menjadi masalah di Indonesia. Penghasilan digunakan masyarakat untuk memenuhi berbagai kebutuhannya. Dalam masyarakat terdapat kelompok

1 Anonimus.2007.Kemiskinan dan Ketimpangan Pendapatan. file:///C:/Users/user/Downloads/ sep_203_handout_kemiskinan_dan_ketimpangan_pendapatan.pdf.Diakses Pada 28 Juni 2014 Pukul 14.35 WIB

2 BPS. Jumlah Penduduk Miskin, Persentase Penduduk Miskin dan Garis Kemiskinan, 1970-2013. http://webbeta.bps.go.id/tab_sub/view. php?kat=1\&tabel=1\&daftar=1\&id_subyek=23 \&notab=7.Diakses Pada 28 Juni 2014 Pukul 1455 WIB 
masyarkat dengan penghasilan tinggi dan kelompok masyarakat dengan penghasilan rendah. Masyarakat yang memiliki penghasilan tinggi mampu memenuhi kebutuhan hidupnya mulai dari kebutuhan primer, sekunder, hingga tersier. Sementara itu, kelompok masyarakat yang memiliki penghasilan rendah tidak mampu memenuhi kebutuhan hidupnya meskipun kebutuhan yang paling dasar.

Perbedaan kelompok masyarakat dengan penghasilan tertentu menimbulkan permasalahan kesenjangan penghasilan. Oleh karena itu, diperlukan peran pemerintah dalam memeratakan penyaluran distribusi pendapatan. Hal ini dilakukan untuk meratakan kemampuan masyarakat dalam menikmati hasil pembangunan. Selain itu, upaya pemerintah dalam meratakan penghasilan bertujuan untuk mengurangi kesenjangan dan kecemburan sosial masyarakat.

Distribusi pendapatan masyarakat merupakan salah satu faktor yang mempengaruhi tingkat kesejahteraan. Perkembangan di banyak negara berkembang menunjukkan bahwa dalam proses tersebut distribusi pendapatan keadaannya menjadi lebih tidak merata. Keadaan ini telah menimbulkan ketidakpuasan terhadap usaha - usaha pembangunan di beberapa negara berkembang. Karena dianggap usaha tersebut hanya menguntungkan sebagian kecil masyarakatnya. Pembangunan ekonomi bukanlah melulu bertujuan untuk menciptakan modernisasi dalam suatu masyarakat, tetapi lebih penting lagi adalah menciptakan kehidupan yang lebih baik kepada seluruh masyarakat tersebut. Secara idiil tujuan pembangunan selalu diinginkan dapat dinikmati masyarakat secara merata. ${ }^{3}$

Merujuk pada Undang - Undang Dasar 1945 Pasal 33 ayat (1) mengatakan bahwa "Perekonomian disusun sebagai usaha bersama berdasarkan atas asas kekeluargaan". Kemudian Pasal 33 ayat (4) menambahkan bahwa "Perekonomian nasional diselenggarakan berdasar atas demokrasi ekonomi dengan prinsip kebersamaan, efisiensi berkeadilan, berkelanjutan, berwawasan lingkungan, kemandirian, serta dengan menjaga keseimbangan kemajuan dan kesatuan ekonomi nasional". Jelas bahwa konstitusi kita menginginkan bahwa perekonomian Indonesia diselenggarakan dengan prinsip kebersamaan dan kekeluargaan agar tujuan negara sebagai negara yang sejahtera dapat tercapai.

Berbagai penyebab pembangunan nasional tidak dapat terlaksana dengan baik seperti tersebut diatas, salah satu yang menjadi pekerjaan rumah yang paling penting bagi pemerintah adalah mengentaskan kemiskinan serta pemerataan pendapatan masyarakat di Indonesia. Kemiskinan menyebabkan perekonomian di Indonesia menjadi menurun. Pasal 3 Undang Undang Nomor 23 Tahun 2011 Pengelolaan Zakat mengatakan bahwa zakat bertujuan untuk meningkatkan efektivitas dan efisiensi pelayanan dalam pengelolaan zakat; dan meningkatkan manfaat zakat untuk mewujudkan kesejahteraan masyarakat dan penanggulangan kemiskinan. Bertolak dari hal tersebut maka penulis merasa perlu mengkaji pemikiran guna menunjang pembangunan perekonomian di Indonesia atau setidaknya menekan kemiskinan dan pemerataan pendapatan masyarakat di Indonesia melalui zakat.

\footnotetext{
Sadono Sukirno, Ekonomi Pembangunan : Proses, masalah dan dasar kebijakan. Kencana Media Group, Jakarta, 2006, hlm. 58-59
} 


\section{B. Rumusan Permasalahan}

Berdasarkan latar belakang sebagaimana sebagai penulis deskripsikan di atas, maka rumusan masalah dari penelitian ini adalah sebagai berikut:

1. Mengapa zakat dapat digunakan sebagai upaya pembangunan ekonomi guna menekan angka kemiskinan serta pemerataan pendapatan nasional?

2. Apakah peraturan pengelolaan zakat yang belaku di Indonesia sudah berjalan secara optimal?

\section{Pembahasan}

1. Zakat Sebagai Upaya Pembangunan Ekonomi guna Menekan Angka Kemiskinan serta Pemerataan Pendapatan Nasional

a. Dasar Hukum Zakat Berdasarkan Hukum Positif di Indonesia

Sejak tahun 1990-an zakat merupakan salah satu instrumen Islam yang strategis dalam pembangunan ekonomi dan semakin populer di Indonesia. Indikasi positif ini selain disebabkan kesadaran menjalankan perintah agama di kalangan umat Islam semakin meningkat dan menunjukkan perkembangan yang baik. Bahkan setelah itu dorongan untuk membayar zakat juga datang dari pemerintah dengan dikeluarkannya Undang - Undang Nomor 38 Tahun 1999 tentang Pengelolaan Zakat. Undang - undang tersebut merupan kelahiran undang - undang pertama yang mengatur mengenai zakat di Indonesia sebagaimana kini telah digantikan dan disempurnakan dengan Undang Undang Nomor 23 Tahun 2011 tentang Pengelolaan Zakat.

Gerakan monumental zakat di Indonesia dicatat sebagai berikut ${ }^{4}$ :

1) Presiden B. J. Habibie pada tanggal 23 September 1999 atas persetujuan DPR telah mensahkan Undang-Undang No. 38 Tahun 1999 tentang Pengelolaan Zakat.

2) Presiden Abdurrahman Wahid pada tanggal 17 Januari 2001 mengeluarkan Keputusan Presiden No. 8 Tahun 2001 tentang Badan Amil Zakat nasional.

3) Presiden Megawati Soekarno Putri pada tanggal 2 Desember 2001 melakukan pencanangan Gerakan Sadar Zakat dalam acara peringatan Nuzulul Qur'an di Masjid Istiqlal Jakarta.

4) Presiden Susilo Bambang Yudhoyono pada tanggal 26 Oktober 2005 melakukan pencanangan Gerakan Zakat Infak dan Shadaqah Nasional dan mengukuhkan Kepengurusan BAZNAS periode 2004 - 2007 di Istana Negara.

Dalam rangka melaksanakan pengelolaan zakat sesuai dengan amanat UndangUndang Nomor 38 Tahun 1999 tentang Pengelolaan Zakat, pemerintah pada tahun 2001 membentuk Badan Amil Zakat Nasional (BAZNAS) dengan Keputusan Presiden. Di setiap daerah juga ditetapkan pembentukan Badan Amil Zakat Provinsi, Badan Amil

4 Ahmad Mujahidin, Ekonomi Islam. PT. Raja Grafindo Persada. Jakarta, 2007, hlm. 70-71 
Zakat Kabupaten/Kota hingga Badan Amil Zakat Kecamatan. Pemerintah juga mengukuhkan keberadaan Lembaga Amil Zakat (LAZ) yang didirikan oleh masyarakat. LAZ tersebut melakukan kegiatan pengelolaan zakat sama seperti yang dilakukan oleh Badan Amil Zakat. Pembentukan Badan Amil Zakat di tingkat nasional dan daerah mengantikan pengelolaan zakat oleh BAZIS (Badan Amil Zakat, Infaq dan Shadaqah) yang sudah berjalan dihampir semua daerah.

Pengelolaan zakat kini sudah diberdayakan melalui profesionalisme pengelolaan, sebagaimana ditegaskan dalam Undang - Undang Nomor 23 Tahun 2011 tentang Pengelolaan Zakat bahwa Baznas (Badan Amil Zakat Nasional) pusat bertugas untuk mengoordinasi seluruh lembaga zakat yang sudah terdaftar. Fokus Baznas adalah sebagai regulator dan bukan operator yang bertujuan untuk mewujudkan suatu sistem yang terkoordinasi, rapi, serta bersinergi. Kemudian di tahun 2014 Pemerintah mengeluarkan Peraturan Pemerintah Nomor 14 Tahun 2014 tentang Pelaksanaan Undang Nomor 23 Tahun 2011 tentang Pengelolaan Zakat.

\section{b. Dasar Hukum Zakat Berdasarkan Syariat Islam}

Dalam ajaran Islam terdapat lima hal yang harus dikerjakan oleh umat Islam, yaitu yang disebut dengan Rukun Islam. Rukun Islam itu terdiri dari syahadat, sholat, puasa, zakat, dan haji (apabila telah mampu). Syahadat merupakan pernyataan bahwa seseorang beriman kepada Allah SWT dan Rasul-Nya, yaitu Muhammad SAW. Sedangkan Rukun Islam yang kedua dan seterusnya itu sebagai perwujudan dari kedua kalimat syahadat tersebut. Kelima hal tersebut merupakan kewajiban bagi umat Islam. Demikian pula dengan zakat. Zakat merupakan kewajiban bagi umat Islam yang dikaitkan dengan harta yang dimiliki oleh seseorang dan tergolong dalam ibadah maliyah atau ibadah harta. Hukum mengeluarkan zakat adalah fardlu 'ain.

Kewajiban zakat merupakan salah satu jalan atau sarana untuk tercapainya keselarasan dan kemantapan hubungan antara manusia dengan Allah SWT serta hubungan manusia dengan manusia lainnya. Dengan kewajiban zakat, selain membina hubungan dengan Allah SWT sekaligus memperdekat hubungan kasih sayang antara sesama manusia, yaitu adanya saling menolong dan saling membantu antara sesama manusia. Kewajiban zakat merupakan salah satu upaya untuk mewujudkan terbentuknya masyarakat yang baldatun tayyibatun warabbun ghaffur, yaitu masyarakat yang baik di bawah naungan keampunan dan keridlaan Allah SWT. ${ }^{5}$

Ayat - ayat Al-Qur'an yang menjelaskan tentang keberadaan zakat diturunkan dalam dua periode, yaitu periode Makkah dan periode Madinah. Ayat al-Qur'an tentang zakat yang diturunkan pada periode Makkah diantaranya tertuang dalam surat 73 ayat 20; "Dan tegakkanlah sholat dan tunaikan zakat dan berilah piutang kepada Allah dengan sebaikbaik piutang". Serta surat 98 ayat 5: "Dan hendaklah mereka mendirikan sholat dan menunaikan zakat dan itulah agama yang lurus".

5 Nur Iman Ramadhona, Analisa Yuridis Tentang Zakat Bagi Pegawai Negeri Sipil (Pns) Di Lihat Dari Perspektif Hukum Islam, 2006, hlm. 10 
Sedangkan ayat-ayat yang diturunkan pada periode Madinah diantaranya surat 2 ayat 43; "Dan dirikanlah sholat dan tunaikanlah zakat dan ruku'lah bersama orang-orang yang ruku". Kemudian surat 2 ayat 110; "Dirikanlah sholat oleh kalian dan tunaikanlah zakat" Serta surat 5 ayat 12; "Sesungguhnya jika kamu mendirikan sholat dan menunaikan zakat dan beriman kepada rasul-Ku..,sesungguhnya Aku akan menutupi dosa-dosa kamu”.

Zakat menurut istilah (syara') artinya sesuatu yang hukumnya wajib diberikan dari sekumpulan harta benda tertentu, menurut sifat dan ukuran tertentu kepada golongan tertentu yang berhak menerimanya dengan syarat tertentu pula. Dalam surat Al-Baqarah : 267 menyatakan bahwa "“'Hai orang-orang yang beriman, nafkahkanlah (di jalan Allah) sebagian dari hasil usahamu yang baik-baik dan sebagian dari apa yang kami keluarkan dari bumi untuk kamu. Dan janganlah kamu memilih yang buruk-buruk lalu kamu menafkahkan daripadanya, padahal kamu sendiri tidak mau mengambilnya melainkan dengan memicingkan mata terhadapnya. Dan ketahuilah, bahwa Allah Maha Kaya lagi Maha Terpuji” (Q.S. Al-Baqarah:267).

Di samping landasan yang sharih dan qath'i dari Al-Qur'an dan Hadits, kewajiban membayar zakat diperkuat pula dengan dalil ijma' para sahabat. Khalifah Abu Bakar, pada awal pemerintahannya dihadapkan dengan satu masalah besar yaitu munculnya golongan yang enggan membayar zakat, sedang mereka mengaku Islam. Berdasarkan ijtihadnya yang didukung sahabat-sahabat lain, maka tanpa ragu beliau mengambil tindakan tegas yaitu memerangi golongan pembangkang tersebut. Dan kewajiban ini terus berlangsung sampai kepada khalifah-khalifah berikutnya. ${ }^{6}$

Orang yang menentang kewajiban zakat dihukumi kafir ; yang enggan menunaikannya diperangi dan dipungut zakat daripadanya secara paksa, sekalipun ia tidak memerangi. Wajib zakat atas setiap muslim, sekalipun tidak Mukallaf ; maka bagi sang wali wajib mengeluarkan zakat untuk orang yang di walii dari hartanya sendiri. Orang kafir asli tidak berkewajiban menunaikan zakat, sekalipun pernah masuk Islam. ${ }^{7}$

c. Peran dan Potensi Zakat di Indonesia

Peran dan manfaat zakat khususnya dalam ekonomi sangat penting dalam usaha pemberdayaan potensi ekonomi masyarakat. Agar zakat berjalan dengan efektif diharapkan tercapai kepastian pemenuhan hak minimal kaum fakir miskin serta berputarnya roda perekonomian masyarakat, mendorong pemanfaatan dana serta harmonisasi kaya dan miskin sehingga kehidupan masyarakat akan terwujud.

Zakat merupakan salah satu pilar syari'at Islam yang memiliki kaitan dengan permasalahan tersebut. Zakat merupakan ibadah dalam Islam yang memiliki dimensi sosial-ekonomi. Zakat berfungsi sebagai media redistribusi kekayaan dari kelompok yang mampu (aghniya') kepada golongan yang kurang mampu (dhuafa') dan yang tertindas

6 Asnaini, Zakat produktif dalam perspektif hukum islam. Pustaka pelajar.cetakan 1, Yogyakarta, 2008, hlm. 23

Aliy As'ad dalam Afe Evanadliyasai. 2012. Pengertian Zakat dan Dasar Hukumnya. http://afeevanadliyasai.blogspot.com/.Diakses Pada 2 Juli 2014 Pukul 12.13 WIB. 
(mustadh'afin). Zakat merupakan institusi resmi syari'at Islam untuk menciptakan kesejahteraan sosial-ekonomi yang berkeadilan, sehingga pembangunan ekonomi mampu menghadirkan kesejahteraan bagi masyarakat.

Banyak orang yang menyamakan pajak dan zakat. Sehingga ketika seseorang sudah membayar pajak menganggap dirinya sudah membayar zakat. Padahal keduanya merupakan hal yang berbeda. Masing-masing memiliki kekhasan tersendiri. Dalam Islam, pelaksanaan zakat merupakan sebuah perintah Allah SWT yang memiliki pesan sebagai sebuah kewajiban yang mutlak harus dilakukan oleh setiap orang yang mengaku dirinya beriman. Hakikat perintah yang disyari'atkan dalam Islam menurut Sayyid Quthb, tidaklah patut dipertanyakan alasan mengapa hal itu ada oleh setiap mu'min yang baik. Tetapi, sikap yang harus ditunjukkan adalah menjalankannya dengan penuh ketaatan, sami'na wa atho'na untuk mendapat keridhaan Allah SWT dan mencari hikmah yang terkandung dalam perintah tersebut. Karena itu, dalam mengkaji zakat, hal yang memungkinkan bisa dilakukan adalah dengan mencari hikmah dan implementasi dari perintah itu ${ }^{8}$.

Terebih lagi melalui mekanisme distribusi harta kekayaan ini, zakat akan meminimalisir terjadinya kesenjangan antara kemajuan ekonomi dengan kesejahteraan sosial. Dengan distribusi kekayaan tersebut, maka tujuan yang lebih spesifik yaitu penyebaran kesejahteraan secara progresif akan terwujud. Laju pertumbuhan ekonomi mampu memberikan kontribusi pendapatan bagi masyarakat yang kurang beruntung, sehingga pertumbuhan ekonomi tidak hanya terjadi pada kelompok yang memiliki modal saja. Tetapi juga tersebar merata bagi mereka yang tergolong miskin, karena adanya tambahan distribusi pendapatan melalui zakat. Oleh karenanya, penerapan zakat dalam pembangunan mampu memacu pembangunan kesejahteraan sosial, bersamaan dengan laju pertumbuhan ekonomi.

Pembangunan sektor riil zakat memiliki peranan yang cukup besar. Peran tersebut diimplementasikan dalam agenda pemberdayaan masyarakat melalui produktifitas dana zakat. Pada dasarnya, zakat merupakan sebuah proses yang produktif dalam pemberdayaan masyarakat. Artinya, pemanfaatan zakat semestinya bukan hanya terpaku pada hal-hal yang bersifat konsumtif, melainkan memiliki agenda pembangunan masyarakat yang terpadu melalui pemberdayaan masyarakat. Seorang mustahiq dengan dorongan keimanan yang tinggi tidak hanya sekedar mencukupkan dirinya untuk menjadi mustahiq selamanya, tetapi ia akan berusaha memanfaatkan dengan baik harta yang dimilikinya, mandiri dalam mengelola harta yang datang kepadanya. Sehingga suatu saat ia tidak lagi menjadi mustahiq, tetapi justru menjadi muzakki baru.

Nilai-nilai yang terkandung dalam kewajiban zakat adalah sama dengan salah satu tujuan nasional Negara Republik Indonesia yang diamanatkan dalam Pembukaan Undang - Undang Dasar 1945, yaitu memajukan kesejahteraan umum. Dengan pengelolaan yang

8 Najmah Saiidah. http://hizbut-tahrir.or.id/2013/ 07/29/zakat-pilar-membangun-masyarakat/. Diakses Pada 2 Juni 2014 Pukul 12.29 WIB. 
baik, zakat merupakan sumber dana yang potensial yang dapat dimanfaatkan untuk memajukan kesejahteraan umum bagi seluruh masyarakat Indonesia. Zakat merupakan kewajiban utama bagi para aghniya, pengusaha dan orang kaya muslim, yang dalam firman allah SWT sering dirangkaikan dengan kewajiban shalat.

Indonesia dengan jumlah muslim terbanyak di dunia sebenarnya memiliki potensi zakat yang cukup besar. Berdasarkan akumulasi perhitungan Baznas, potensi zakat di Indonesia dapat mencapai Rp 217,3 triliun tiap tahunnya. Namun pada kenyataannya jumlah zakat yang terealisasi bahkan tidak mencapai $10 \%$ dari jumlah yang ditargetkan. Terhitung pada tahun 2012 mulai bulan Januari hingga bulan Oktober, penerimaan zakat baru mencapai Rp1,7 triliun. Jumlah itu memang melebihi pengumpulan zakat nasional pada tahun 2011 yakni sebesar Rp1,5 triliun. ${ }^{9}$

Hasil zakat yang terkumpul digunakan untuk berbagai kegiatan sosial dan keagamaan, seperti: pendirian rumah sehat Baznas, pendirian rumah cerdas anak bangsa, baitul qiradh, tanggap darurat bencana, dan pusat pelayanan musatahiq. Selain itu juga zakat telah membantu 1,7 juta orang mustahiq setiap tahunnya, disamping dana Rp 73,7 trilliun per tahun yang dikeluarkan pemerintah untuk mengentaskan kemiskinan. ${ }^{10}$

Berdasarkan penelitian tahun 2011 yang dilakukan Baznas bekerja sama dengan Institut Pertanian Bogor (IPB), diketahui bahwa potensi zakat di Indonesia sampai tahun 2013 sangat besar, yaitu sekitar 217 triliun atau sebesar 3,4 persen dari PDB Indonesia. Hasil penghimpunan zakat dari lembaga-lembaga zakat tahun 2012 mencapai Rp 2,2 triliun. Jelas masih ada banyak kesenjangan antara potensi dan realisasi penerimaan zakat. $^{11}$

Meski demikian, ada kemajuan yang signifikan dilihat dari penerimaan zakat setiap tahun. Pada 2008 mencapai Rp 920 miliar, tahun 2009 mencapai Rp 1,2 triliun atau ada peningkatan sebesar 30,43 persen dibandingkan tahun sebelumnya. Penerimaan tahun 2010 sebesar Rp 1.5 triliun atau meningkat sebesar 25 persen, tahun 2011 mencapai Rp 1,73 triliun atau meningkat sebesar 15 persen, dan tahun 2012 mencapai Rp 2.2 triliun meningkat sebesar 27,17 persen. ${ }^{12}$

Indonesia adalah negara Muslim terbesar di dunia dari sisi jumlah penduduk. Namun kesadaran masyarakat Muslim untuk membayar zakat masih rendah, sehingga penerimaan zakat juga kurang optimal. Kesadaran membayar zakat, masih sebatas membayar zakat fitrah yang dikeluarkan saat puasa Ramadan. Padahal potensi zakat lain nilainya bisa lebih tinggi lagi, antara lain zakat dari kepemilikan emas dan perak,

9 Anonimus.2013.Relevansi Zakat di Indonesia. http://sharingmahasiswa.blogspot.com/2013/04/relevansizakat-di-indonesia.html.Diakses Pada 2 Juni 2014 Pukul 13.11 WIB.

10 Ibid.

11 Anonimus.2013.Optimalisasi Pengelolaan dan Regulasi Zakat. http://www.beritasatu.com/ blog/ekonomi/2764-optimalisasi-pengelolaan-dan-regulasi-zakat.html.Diakses Pada 2 Juni 2014 Pukul 12.44 WIB

12 Ibid. 
pertanian, perdagangan, uang simpanan atau deposito, investasi, hadiah atau bonus perusahaan, hibah dan peternakan.

Jika hanya zakat fitrah yang dihitung, maka jumlahnya tidak terlalu besar. Dengan memperhitungkan jumlah penduduk Indonesia mencapai 230 juta jiwa dan populasi Muslim diperkirakan mencapai 87 persen, maka populasi Muslim kurang lebih ada sekitar 200 juta jiwa. Jika jumlah penduduk miskin Indonesia ada sekitar 30 persen dan penduduk hampir miskin sekitar 20 persen, maka wajib zakat ada sekitar 100 juta jiwa. Jika setiap jiwa mengeluarkan zakatnya sebesar 2,5 kg atau setara dengan $\mathrm{Rp} 25.000$, maka potensi zakat fitrah mencapai Rp 2,5 triliun. ${ }^{13}$

Potensi terbesar adalah zakat mal. Berdasarkan analisis perhitungan Litbang Kompas (Kompas, 3 Agustus 2013), potensi zakat dari penghasilan profesi tak kurang dari Rp 6,7 triliun per bulan atau Rp 80,3 triliun per tahun. Jumlah tersebut dihitung dengan asumsi nilai penghasilan minimal kena zakat (nisab) saja. Jadi, potensi zakat sesungguhnya bisa lebih tinggi lagi. Karena jumlah tersebut hanya potensi dari zakat profesi (penghasilan). Padahal potensi zakat lain nilainya bisa lebih tinggi lagi, antara lain zakat dari kepemilikan emas dan perak, pertanian, perdagangan, uang simpanan atau deposito, investasi, hadiah atau bonus perusahaan, hibah dan peternakan.

Data Bank Indonesia menyebutkan jumlah simpanan dalam bentuk giro, tabungan dan simpanan berjangka, baik dalam mata uang rupiah maupun asing pada akhir tahun 2012, sebesar Rp 3.225 triliun. Jika diasumsikan separuhnya dari simpanan dana itu milik umat Islam, estimasi zakat mal setelah setahun jumlahnya tak kurang dari Rp 40 triliun. ${ }^{14}$

Potensi pertumbuhan kelas menengah Muslim juga terus meningkat seiring dengan meningkatnya kualitas pendidikan dan kualitas kesejahteraannya. Kualitas kesejahteraan berbanding lurus dengan pertumbuhan ekonomi yang terus membaik, sehingga banyak muncul kelas menengah baru.

\section{Implementasi dan Optimalisasi Peraturan Pelaksanaan Zakat di Indonesia}

a. Pelaksanaan, Kesulitan dan Tantangan yang Dihadapi dalam Pengelolaan Zakat di Indonesia

Zakat secara terorganisasi dan profesional dimaksudkan agar zakat memberi manfaat optimal dalam pembinaan umat. Minimal ada nilai-nilai yang hendak diwujudkan, seperti mengupayakan zakat sebagai salah satu solusi bagi masalah perekonomian yang dihadapi sebagian besar masyarakat, yakni kemiskinan, pengangguran, dan kesenjangan. Bahkan untuk negara - negara tertentu, zakat sudah diarahkan untuk memberikan kontribusi bagi pembangunan, yakni sebagai instrumen jaminan sosial dalam upaya mengurangi kesenjangan antara si miskin dan si kaya serta memperkuat kemandirian ekonomi. 
Tentu saja untuk mewujudkan harapan itu, pengelolaan zakat harus dilakukan secara terpadu dari lembaga penarik zakat dan secara bersama-sama menggerakkan zakat untuk memberdayakan umat. Jika zakat hanya menjadi gerakan individual yang tidak dikelola secara bersama sama, maka optimalisasi zakat hanya bersifat sementara dan tidak berkesinambungan.

Namun untuk mewujudkan pemberdayaan zakat secara berkesinambungan, masih ada sejumlah kendala, di antaranya: ${ }^{15}$

1) Rendahnya tingkat kesadaran umat dalam menunaikan kewajiban zakat. Banyak orang kaya yang punya tabungan ratusan juta rupiah. bahkan miliaran rupiah, belum semuanya sadar untuk membayar zakat.

2) Rendahnya tingkat kepercayaan para muzaki terhadap pengelola zakat, baik yang berasal dari masyarakat maupun dari aparat pemerintah. Hal itu terkait dengan kondisi tingkat integritas dan kejujuran aparat pemerintah yang masih rendah. Para muzaki masih meragukan mental dan perilaku aparat. Hal ini terbukti dengan banyaknya kasus korupsi di negeri ini. Akibatnya berimbas pada rendahnya tingkat kepercayaan masyarakat terhadap kejujuran aparat pemerintah yang ditugasi mengelola zakat.

3) Masih terdapat silang pendapat di antara ulama dalam zakat profesi. Sebagian ulama berpendapat wajib, dan sebagian lainnya mengatakan tidak wajib. Bagi ulama yang menyatakan wajibnya zakat profesi adalah di-qiyas-kan dengan zakat pertanian. Begitu pertanian panen dan telah memenuhi nishab-nya, wajib berzakat, tanpa harus menunggu haul (tahun). Sementara ulama yang menyatakan zakat profesi tidak wajib berargumentasi tidak ada dalilnya. Padahal potensi hasil dari zakat profesi ini cukup besar.

Indonesia sudah memiliki landasan yang kuat untuk mengoptimalkan pengelolaan zakat melalui Undang - Undang Nomor 23 Tahun 2011 tentang Pengelolaan Zakat, namun harus diakui implementasinya belum optimal. Meski sudah berjalan, namun undang - undang tersebut belum optimal sebagai landasan operasional dalam upaya menyukseskan gerakan zakat. Melalui undang undang tersebut diharapkan pengumpulan zakat dapat dikelola secara profesional dengan kemanfaatan secara berkelanjutan untuk umat. Zakat tidak hanya dkelola secara partisipatif individual, tetapi juga tersentralisasi secara kelembagaan.

Sentralisasi pengelolaan zakat juga dilakukan Rasulullah SAW dan para kalifah dan merupakan sentralisasi pengelolaan zakat pada negara, karena Rasulullah saw dan para khalifah yang mengumpulkan dan mengelola zakat dalam kapasitas sebagai penguasa. Namun Indonesia bukan negara agama, tetapi negara dengan mayoritas berpenduduk Muslim, diperlukan jalan tengah, yakni peran negara dan masyarakat tidak dalam posisi

15 Anonimus.2013.Optimalisasi Pengelolaan dan Regulasi Zakat. http://www.beritasatu.com/ blog/ekonomi/2764-optimalisasi-pengelolaan-dan-regulasi-zakat.html.Diakses Pada 2 Juni 2014 Pukul 14.30 WIB 
paradoksal, melainkan dua posisi yang bersinergi. Peran negara dalam pelayanan sosial keagamaan tetap berjalan, tanpa mengabaikan partisipasi masyarakat atau individu. Tentu saja komitmen serius dari kalangan ulama dan intelektual muslim juga sangat diperlukan. ${ }^{16}$ Artinya, pelaksanaan zakat hendaknya tidak dibiarkan berjalan begitu saja, tidak ada yang mengurusi secara sungguh-sungguh. Karena nanti hasilnya tidak akan pernah mampu menjawab problematika yang dihadapi masyarakat miskin. Zakat akan tidak memiliki dalam implementasinya.

\section{b. Optimalisasi Peraturan Pelaksanaan Zakat di Indonesia}

Ketika muncul pertanyaan apakah pelaksanaan pengelolaan zakat melalui undang undang pengelolaan zakat sudah berjalan maksimal maka jawabannya adalah tentunya belum maksimal melihat begitu besar potensi zakat sebagai upaya pengentasan kemiskinan oleh pemerintah namun pelaksanan masih sangat jauh dari harapan.

Optimalisasi zakat dapat ditempuh melalui penguatan tata kelola zakat, penguatan kelembagaan organisasi zakat, penguatan regulasi dan penegakkan hukumnya, termasuk perlunya dukungan politik dan penguatan pengawasan zakat. Dengan masuknya pemerintah sebagai agen utama penggerak zakat, maka zakat nantinya bisa diharapkan membawa manfaat sebagai pilar redistribusi kesejahteraan nasional. Dan dalam pelaksanaannya, idealnya memang zakat dikelola oleh negara, yang ditujukan bagi kesejahteraan masyarakat. Seperti dalam konstitusi kita Pasal 34 ayat (1) UUD 1945 menyatakan bahwa fakir miskin dan anak - anak terlantar dipelihara oleh negara.

Target keberhasilan lembaga pengelola zakat adalah bagaimana kita bisa meningkatkan harkat kehidupan Warga Masyarakat yang berada dibawah garis kemiskinan, sehingga bisa mengurangi kemiskinan tersebut. Salah satu potensi zakat yang cukup signifikan dalam perekonomian modern adalah Zakat perusahaan. Indonesia bisa mengambil komparasi pada praktik zakat Perusahaan di negara lain seperti di malasyia, Jeddah yang sudah berjalan baik. bahkan saham Perusahaan wajib dizakati oleh pemilik saham, dengan arti bahwa semua saham yang terdapat dalam perusahaan tertentu dianggap sebuah harta milik seseorang. ${ }^{17}$

Walaupun zakat bersifat lebih kepada kesejahteraan sosial, institusi zakat di Indonesia lebih lemah dari institusi pajak. Hal ini dapat kita lihat dari gencarnya pemerintah menggalakan pajak dibandingkan dengan zakat. Hal yang sama juga terjadi pada istitusi zakat Malaysia, dimana belum memiliki perundang-undangan yang kuat untuk menjerat orang-orang yang tidak mau membayar zakat. Zakat hanya dijadikan sumbangan sukarela dan bersifat pribadi atau antara individu dengan Tuhannya.

Ketentuan zakat yang statis menyebabkan tidak memadainya dana zakat untuk memenuhi kebutuhan pembangunan masyarakat dan negara. Oleh karena itu,

16 Anonimous.2013.Opcit.

17 Hj. Siti Saidah. 2014.Analisa tentang Pengelolaan Zakat pada waktu Sosialisasi UU Pengelolaan Zakat dan Penyuluhan Zakat. Untuk di Tingkat Daerah Provinsi. http://jabar. kemenag.go.id/index.php?a=artikel\&id=\%2024291.Diakses Pada 2 Juni 2014 Pukul 14.32 WIB 
dimungkinkan ditariknya dana dari masyarakat melalui jalur pajak dan sumbangan sukarela lainnya. Di Indonesia dengan dasar Peraturan Pemerintah Nomor 571 dan Undang - Undang Nomor 17 Tahun 2000 tentang Pajak Penghasilan memungkinkan rabat, yaitu pemotongan pajak penghasilan bagi mereka yang telah membayar zakat. Walaupun belum sesempurna dibanding Undang-Undang Pajak dan Zakat yang ada di Malaysia misalnya atau negara Islam lainnya yang sudah maju.

Zakat atas penghasilan boleh dikurangkan dari Penghasilan Kena Pajak. Zakat atas penghasilan yang dapat dikurangkan tersebut harus nyata-nyata dibayarkan oleh Wajib Pajak orang pribadi pemeluk agama Islam dan atau Wajib Pajak badan dalam negeri yang dimiliki oleh pemeluk agama Islam kepada badan amil zakat atau lembaga amil zakat yang dibentuk atau disahkan oleh Pemerintah sebagaimana diatur dalam Undang-undang Nomor 38 Tahun 1999 tentang Pengelolaan Zakat, dan sepanjang berkenaan dengan penghasilan yang menjadi Objek Pajak dapat dikurangkan dalam menghitung besarnya Penghasilan Kena Pajak pada tahun zakat tersebut dibayarkan. Pelaksanaan pasal tersebut masih berlaku meskipun Undang - Undang tentang Pengelolaan Zakat telah diganti dengan Undang - Undang Nomor 23 Tahun 2011 tentang Pengelolaan Zakat sebab dalam Pasal 44 Ketentuan penutup Peraturan Perundang-undangan tentang Pengelolaan Zakat dan peraturan pelaksanaan Undang-Undang Nomor 38 Tahun 1999 tentang Pengelolaan Zakat dinyatakan masih tetap berlaku sepanjang tidak bertentangan dengan ketentuan dalam Undang-Undang ini.

Pada konteks pengelolaan zakat di Indonesia, desentralisasi kewenangan diberikan ruang yang cukup luas pada Undang - Undang Nomor 23 tahun 2011 tentang Pengelolaan Zakat, di mana negara memberikan kedudukan yang sejajar bagi masyarakat bersama pemerintah untuk bersama-sama mengelola dana publik keagamaan (zakat, infak, sedekah, dan dana lainnya). Indonesia kemudian dikenal dua macam lembaga pengelola zakat, yaitu BAZ (Badan Amil Zakat) yang dibentuk oleh pemerintah dan LAZ (Lembaga Amil Zakat) yang laksanakan oleh masyarakat sipil. Hal ini berbeda dengan negara lain yang hanya mengenal single-authority seperti Saudi Arabia, Pakistan, atau Sudan. Kesetaraan posisi di mata hukum antara lembaga zakat bentukan pemerintah maupun masyarakat sipil juga jelas tertera pada pasal 8 Undang - Undang Nomor 38 Tahun 1999 yang menyamakan tugas pokok kedua lembaga ini, yaitu untuk mengumpulkan, mendistribusikan, dan mendayagunakan zakat.

Pada Undang - Undang Nomor 23 tahun 2011 tentang Pengelolaan Zakat BAZNAS sebagai lembaga bentukan pemerintah, berwenang melakukan tugas pengelolaan zakat secara nasional dengan dibekali 4 fungsi dasar, yaitu perencanaan (planning), pelaksanaan (operating), pengendalian (supervising), serta koordinator (coordinating) 
pelaporan zakat di semua tingkatan. Sementara masyarakat melalui LAZ diberikan ruang untuk membantu BAZNAS dalam melakukan kerja-kerja pengelolaan zakat. ${ }^{18}$

BAZNAS dan LAZ seharusnya menjadi 'satu tubuh', satu-kesatuan dalam pengelolaan dan pendistribusian zakat dimana BAZNAS berperan sebagai koordinator. Karena itu, peran dan fungsi BAZNAS dan LAZ dalam mengelola zakat tidak boleh dipandang secara terpisah demi efektivitas pengelolaan dan penyaluran zakat. Adanya dualisme tersebut hendaknya dijadikan satu tubuh dan dilaksanakan sepenuhnya oleh pemerintah.

Tujuan pemungutan zakat dilakukan oleh pemerintah adalah agar para pemberi zakat tidak merasa bahwa yang dikeluarkan itu sebagai kebaikan hati, bukan kewajiban dan para fakir tidak merasa berhutang budi kepada orang kaya. Selain itu terdapat beberapa keuntungan apabila zakat dipungut oleh pemerintah, yaitu:

1) Para wajib zakat lebih disiplin dalam menunaikan kewajibannya dan fakir miskin lebih terjamin haknya;

2) Perasaan fakir miskin lebih dapat dijaga, tidak merasa seperti orang yang memintaminta;

3) Pembagian zakat akan menjadi lebih tertib;

4) Zakat yang diperuntukkan bagi kepentingan umum seperti sabilillah misalnya dapat disalurkan dengan baik karena pemerintah lebih mengetahui sasaran pemanfaatannya.

Selain itu karena banyaknya lembaga/orang pengumpul dana zakat yang beroperasi, kualitas Badan/Lembaga Amil Zakat atai LAZ yang sangat beragam belum ada standardisasi profesi Amil, Rendahnya transparansi pengelolaan zakat oleh LAZ, belum ada cerita sukses bahwa pemberdayaan zakat (mustahik berubah menjadi muzaki). Demi terwujudnya pengelolaan zakat untuk mengurangi angka kemiskinan dibutuhkan dan sangat diperlulan campur tangan pemerintah; Pertama, zakat bukanlah bentuk kedermawanan, melaikan kewajiban bagi setiap orang muslimim. Pemerintah boleh memaksa kepada orang Islam yang wajib membayar zakat. Kedua, Banyaknya lembaga zakat yang bermunculan. Ketiga, agar dana zakat dapat di salurkan secara tepat, efisien dan efektif sehingga mencapai tujuan zakat itu sendiri seperti meningkatkan taraf hidup masyarakat. $^{19}$

Target keberhasilan lembaga pengelola zakat bukanlah mengumpulkan dana zakat sebanyak - banyaknya, tapi bagaimana dana zakat itu dapat disalurkan dengan optimal dan diterima oleh orang - orang yang berhak menerima zakat tersebut. Dengan begitu kita bisa meningkatkan harkat kehidupan Warga Masyarakat yang berada dibawah garis

18 Arif R Haryono.2012. Zakat Act and Management of Public Trust. http://www.imz. or.id/new/article/1500/zakat-law-and-management-of-public-trust/.Diakses Pada 2 Juni 2014 Pukul 12.29 WIB

19 Nurudin MHd Ali, Zakat Sebagai Instrumen Dalam Kebijakan Fiskal, Dunia Grafindo, Jakarta, 2006, hlm. 25 
kemiskinan, sehingga bisa mengurangi kemiskinan tersebut melalui pembangunan perekonomian bangsa.

Pembangunan adalah suatu proses perencanaan social (social plan) yang dilakukan oleh birokrat perencana pembangunan, untuk membuat perubahan social yang akhirnya dapat mendatangkan peningkatan kesejahteraan bagi masyarakat. Pentingnya peran dari Hukum dan ekonomi sangatlah suatu hal yang esensial dalam pembangunan di Negara Indonesia.

Hukum pada hakikatnya adalah suatu perangkat instrument yang di tangan sebuah institusi kekuasaan yang akan difungsikan untuk mengontrol perilaku warga dalam kehidupan mereka sehari-hari. Sebagai instrument control, hukum itu ditenggarai oleh sifatnya yang komprehensif, tak pernah berharap kesediaan warga untuk secara sukarela menaatinya serta pelaksanaanya disertai ancaman sanksi.

Suatu gagasan yang cemerlang, yang dilandasi oleh ajaran Islam yang kuat seperti dikemukakan di atas, para pendiri bangsa ini (the founding fathers) telah memposisikan negara sebagai penanggung jawab utama terhadap penanggulangan masalah kemiskinan. Landasan ideologi inilah yang mendorong pemerintah dengan berbagai macam programnya melalui berbagai departemen, dengan dana yang cukup besar, melakukan kegiatan penanggulangan kemiskinan, baik bantuan secara langsung maupun melalui kegiatan penguatan sektor riil, sejak zaman kemerdekaan sampai dengan sekarang. ${ }^{20}$

Pengesahan undang - undang pengelolaan zakat di Indonesia merupakan usaha pemerintah dalam pengelolaan zakat yang bersifat nasional semakin intensif. Pasca dikeluarkannya Undang-Undang Nomor 38 Tahun 1999 tentang Pengelolaan Zakat, lembaga-lembaga zakat pun banyak bermunculan. Manajemen dan jaringan lembagalembaga itu diperbaiki dan semakin baik sehingga dapat menjadi suatu gerakan tersendiri bagai pemberdayaan ekonomi umat (masyarakat). Namun demikian, potensi zakat yang sebenarnya menurut banyak kalangan belum dapat digali secara maksimal. Hal demikian karena zakat masih dianggap sebagai sumbangan sukarela dan negara tidak dapat memaksa para wajib zakat untuk membayarnya. ${ }^{21}$

Hal tersebut harus diakui bahwa dalam peraturan-peraturan tersebut masih banyak kekurangan yang sangat mendasar, misalnya tidak dijatuhkannya sanksi bagi muzakki yang melalaikan kewajibannya (tidak mau berzakat. Selain ini permasalahan lain yang masih menjadi kekurangan undang-undang tersebut antara lain sebagai berikut:

a. Tidak memberikan tanggungjawab atas amil zakat atau BAZ untuk bertindak dan bertanggungjawab memungut zakat terhadap muzakki.

20 Didin Hafidhuddin (Ketua BAZNAS). http://bazrancasari.wordpress.com/artikel/pembangunan-ekonomiumat-berbasis-zakat/.Diakses Pada 2 Juni 2014 Pukul 12.23 WIB

21 Ali Boron.2010.Pengelolaan Zakat di Indonesia: Perspektif Peran Negara. http://aliboron. wordpress.com/2010/10/26/pengelolaan-zakat-di-indonesia-perspektif-peran-negara/.Diakses Pada 28 Juni 2014 Pukul 15.21 WIB 
b. BAZ tidak dibebankan tanggungjawab meneliti dan menghitung harta muzakki. Sedangkan muzakki sama sekali tidak dibebankan sanksi dalam hal melanggar ketentuan-ketentuan zakat.

c. Tidak ada mekanisme yang jelas apabila muzakki membagi-bagi zakatnya kepada mustahiq, apakah perlu memberikan bukti pembayaran zakat kepada BAZ, kemudian disahkan oleh BAZ dan semestinya bisa digunakan sebagai bukti ketika membayar pajak, guna mendapatkan pengurangan, sesuai dengan besar zakat yang telah dikeluarkan.

Lawrence Friedman melihat bahwa keberhasilan penegakan hukum selalu mensyaratkan berfungsinya semua komponen sistem hukum. Sistem hukum dalam pandangan Friedman terdiri dari tiga komponen yakni komponen struktur hukum, substansi hukum, dan budaya hukum. Keberhasilan penegakan hukum zakat di Indonesia ketika diukur dari ketiga komponen sistem hukum Friedman maka dibutuhkan struktur hukum, substansi hukum serta budaya hukum yang selaras sehingga tujuan yang diharapkan dapat tercapai yaitu menuju kesejahteraan sesungguhnya.

Hukum sebagai instrument control yang bisa memberikan sanksi maka undang undang perlu menerapkan sanksi kepada para muzakki yang melalaikan kewajibannya. Sanksi tersebut harus dicantumkan dengan jelas dan tegas dalam undang - undang sehingga memiliki kekuatan hukum yang dapat mengikat. Upaya optimalisasi pelaksanaan pengelolaan zakat dapat dilakukan dengan revisi undang - undang pengelolaan zakat yang dalam muatan isi terdapat ketentuan sanksi bagi muzakki yang tidak membayar zakat. Sanksi tersebut dapat berupa sanksi denda kepada muzakki yang enggan membayar zakat dengan begitu harapan ke depan pengelolaan zakat dapat berjalan dengan optimal sesuai dengan potensinya.

Salah satu fungsi hukum dalam pembangunan ekonomi adalah stabilitas yakni menciptakan stabilitas ekonomi karena hukum mempunyai kekuasaan memaksakan berlakunya hukum. Sehingga optimalisasi pengelolaan zakat di Indonesia dengan bantuan hukum melalui instrumen hukum dapat dilakukan guna pembangunan perekonomian.

\section{Penutup}

\section{Kesimpulan}

Permasalahan ekonomi yang dialami Indonesia yang mendasar adalah Kemiskinan. Kemiskinan merupakan keadaan masyarakat yang tidak mampu memenuhi kebutuhan hidupnya. Berdasarkan data Badan Pusat Statistik (BPS) bulan Maret 2013 jumlah penduduk yang berada dalam garis kemiskinan berjumlah sekitar 28,07 juta jiwa (11,37\%). Selain kemiskinan Kesenjangan Penghasilan juga menjadi masalah di Indonesia. Dalam masyarakat terdapat kelompok masyarkat dengan penghasilan tinggi dan kelompok masyarakat dengan penghasilan rendah. Oleh karena itu, diperlukan peran pemerintah dalam memeratakan 
penyaluran distribusi pendapatan agar tercapai tujuan negara yaitu menuju negara kesejahteraan.

Berawal dari permasalahan ekonomi tersebut kemudian muncul gagasan syariah yaitu pengoptimalan zakat yang merupakan kewajiban bagi umat Islam mengingat Indonesia merupakan negara dengan penduduk beragama Islam terbanyak di Dunia. Pengelolaan zakat diatur dalam Undang - Undang Nomor 23 Tahun 2011 tentang Pengelolaan Zakat. Hukum pada hakikatnya adalah suatu perangkat instrument yang di tangan sebuah institusi kekuasaan yang akan difungsikan untuk mengontrol perilaku warga dalam kehidupan mereka sehari-hari. Sebagai instrument control, hukum itu ditenggarai oleh sifatnya yang komprehensif, tak pernah berharap kesediaan warga untuk secara sukarela menaatinya serta pelaksanaanya disertai ancaman sanksi.

Potensi zakat di Indonesia sangat menggembirakan. Maka apabila pengelolaan zakat dilakukan secara optimal maka penulis yakin bahwa setidaknya angka kemiskinan dan ketimpangan pendapatan masyarakat di Indonesia bisa ditekan sehingga dapat memberikan sumbangsih bagi kemajuan perekonomian di Indonesia. Namun yang terjadi di Indonesia saat ini kesadaran masyarakat Muslim untuk membayar zakat masih rendah, sehingga penerimaan zakat juga kurang optimal. Kesadaran membayar zakat, masih sebatas membayar zakat fitrah yang dikeluarkan saat puasa Ramadan.

Indonesia bukan negara agama, tetapi negara dengan mayoritas berpenduduk Muslim, diperlukan jalan tengah, yakni peran negara dan masyarakat dalam dua posisi yang bersinergi. Peran negara dalam pelayanan sosial keagamaan tetap berjalan, tanpa mengabaikan partisipasi masyarakat atau individu. Tentu saja komitmen serius dari kalangan ulama dan intelektual muslim juga sangat diperlukan.

Undang - undang pengelolaan zakat selama ini berjalan kurang optimal sebab potensi zakat yang begitu besar guna menekan angka keminkinan dan pemerataan pendapatan di Indonesia belus sesuai dengan kenyataannya. Oleh karena itu perlu peran hukum sebagai economic control serta berfungsi menciptakan stabilitas ekonomi dengan memaksakan berlakunya hukum maka revisi undang - undang pengelolaan zakat perlu dilakukan guna menambahkan sanksi bagi muzakki yang tidak membayar zakat sebagai kewajibannya. Sehingga zakat dengan bantuan hukum negara dapat terlaksana dengan baik sesuai potensinya.

Ketika pengelolaan zakat dilaksanakan sesuai dengan syariat Islam, amanah, berasaskan kemanfaatan, keadilan dan kepastian hukum serta terintegrasi maka niscaya dapat menekan angka kemiskinan dan ketimpangan pendapatan masyarakat di Indonesia sehingga Indonesia dapat selangkah lebih maju menuju negara yang sejahtera.

\section{Saran}

a. Undang - Undang Nomor 23 Tahun 2011 tentang Pengelolaan Zakat belum secara tegas memberikan sanksi kepada muzaki yang tidak membayar zakat. Padahal salah satu fungsi hukum dalam pembangunan ekonomi adalah fungsi stabilitas yakni 
hukum untuk menciptakan stabilitas ekonomi karena hukum mempunyai kekuasaan untuk memaksakan berlakunya hukum.

b. Undang - Undang Nomor 23 Tahun 2011 tentang Pengelolaan Zakat mengenai pendistribusian zakat mekanismenya diserahkan sesuai syariat Islam. Pada prakteknya sendiri pendistribusian zakat oleh LAZ belum transparan sehingga muzaki tidak memiliki kepercayaan pada BAZNAZ maupun LAZ bahwa zakat yang mereka bayarkan telah disaluran dengan benar.

c. Perlunya SDM yang memadai serta profesional yang dapat mengurusi pengelolaan zakat dengan baik sehingga dapat berjalan dengan optimal.

d. Sebagai umat Islam di Indonesia atau muzaki hendaknya membayar zakat sesuai dengan ketentuan undnag - undang dan syariat Islam karena hal tersebut merupakan kewajiban bagi umat Islam.

e. Perlu adanya peningkatan keimanan bagi pemeluk agama Islam di Indonesia.

f. Kepada mustahik hendaknya mengelola zakat yang diberikan dengan baik agar kelak dapat menjadi muzaki baru.

g. Perlu adanya bukti pembayaran zakat yang disahkan oleh Baznas dan semestinya bisa digunakan sebagai bukti ketika membayar pajak, guna mendapatkan pengurangan, sesuai dengan besar zakat yang telah dikeluarkan.

h. Pengelolaan zakat hendaknya dilaksanakan oleh pemerintah dengan suatu lembaga yang independen karena saat ini terjadi dualisme pengelolaan zakat yaitu Baznas dan LAZ. Baznas dan LAZ seharusnya menjadi 'satu tubuh', satu-kesatuan dalam pengelolaan dan pendistribusian zakat dimana Baznas berperan sebagai koordinator. Karena itu, peran dan fungsi Baznas dan LAZ dalam mengelola zakat tidak boleh dipandang secara terpisah demi efektivitas pengelolaan dan penyaluran zakat. Adanya dualisme tersebut hendaknya dijadikan satu tubuh dan dilaksanakan sepenuhnya oleh pemerintah.

\section{Daftar Pustaka}

\section{Buku}

Ahmad Mujahidin, Ekonomi Islam. PT. Raja Grafindo Persada, Jakarta, 2007,

Asnaini, Zakat produktif dalam perspektif hukum islam, Cetakan 1, Pustaka pelajar, Yogyakarta, 2008,

Nur Iman Ramadhona, Analisa Yuridis Tentang Zakat Bagi Pegawai Negeri Sipil (Pns) Di Lihat Dari Perspektif Hukum Islam, 2006,

Nurudin MHd Ali, Zakat Sebagai Instrumen Dalam Kebijakan Fiskal, Dunia Grafindo, Jakarta, 2006, 
Sadono Sukirno, Ekonomi Pembangunan : Proses, masalah dan dasar kebijakan, Kencana Media Group, Jakarta, 2006,

\section{Internet}

Ali Boron, Pengelolaan Zakat di Indonesia: Perspektif Peran Negara. http://aliboron.wordpress.com/2010/10/26/pengelolaan-zakat-di-indonesia-perspektifperan-negara/. Diakses Pada 28 Juni 2014 Pukul 15.21 WIB.

Aliy As'ad dalam Afe Evanadliyasai. Pengertian Zakat dan Dasar Hukumnya. http://afeevanadliyasai. blogspot.com/, 2012, Diakses Pada 2 Juli 2014 Pukul 12.13 WIB.

Anonimus, Kemiskinan dan Ketimpangan Pendapatan. file:/// C:/Users/user/Downloads/sep_203_handout_kemiskinan_dan_ketimpangan_pendapat an.pdf, 2007, Diakses Pada 28 Juni 2014 Pukul 14.35 WIB.

Anonimus, Optimalisasi Pengelolaan dan Regulasi Zakat. http://www. beritasatu.com/ blog/ekonomi/2764-optimalisasi-pengelolaan-dan-regulasi-zakat.html, Diakses Pada 2 Juni 2014 Pukul 12.44 WIB.

Anonimus, Relevansi Zakat di Indonesia. http://sharingmahasiswa.blogspot.com/2013/04/ relevansi-zakat-di-indonesia.html.Diakses Pada 2 Juni 2014 Pukul 13.11 WIB.

Arif R Haryono, Zakat Act and Management of Public Trust. http://www.imz.or.id/ new/article/1500/zakat-law-and-management-of-public-trust/, Diakses Pada 2 Juni 2014 Pukul 12.29 WIB.

BPS, Jumlah Penduduk Miskin, Persentase Penduduk Miskin dan Garis Kemiskinan, 19702013, http://webbeta.bps.go.id/tab_sub/view.php?kat=1\&tabel=1\&daftar=1\&id_ subyek=23\&notab=7.Diakses Pada 28 Juni 2014 Pukul 1455 WIB.

Didin Hafidhuddin (Ketua BAZNAS). http://bazrancasari.wordpress.com/artikel/ pembangunan-ekonomi-umat-berbasis-zakat/, Diakses Pada 2 Juni 2014 Pukul 12.23 WIB.

Najmah Saiidah, http://hizbut-tahrir.or.id/2013/07/29/zakat-pilar-membangun-masyarakat/, Diakses Pada 2 Juni 2014 Pukul 12.29 WIB.

Siti Saidah, Analisa tentang Pengelolaan Zakat pada waktu Sosialisasi UU Pengelolaan Zakat dan Penyuluhan Zakat, Untuk di Tingkat Daerah Provinsi. http://jabar.kemenag.go.id/index.php?a=artikel\&id=\%2024291, Diakses Pada 2 Juni 2014 Pukul 14.32 WIB. 